\title{
Special Educational Needs and the Study at the Field of Medicine
}

\author{
Hana Sochorova, Ivona Zavacka \\ Department of Biomedical Sciences, Faculty of Medicine, University of Ostrava, Ostrava, Czech Republic \\ Email: hana.sochorova@osu.cz
}

How to cite this paper: Sochorova, H., \& Zavacka, I. (2018). Special Educational Needs and the Study at the Field of Medicine. Creative Education, 9, 1258-1276.

https://doi.org/10.4236/ce.2018.98094

Received: March 7, 2018

Accepted: June 26, 2018

Published: June 29, 2018

Copyright $(\odot) 2018$ by authors and Scientific Research Publishing Inc. This work is licensed under the Creative Commons Attribution-NonCommercial International License (CC BY-NC 4.0). http://creativecommons.org/licenses/by-nc/4.0/ (c) (i) (8) Open Access

\begin{abstract}
The study and the profession at the field of medicine involve high demands on mental and physical capabilities. The objective of this study is the following issue: in what ways mainly healthy students evaluate opportunities of students with special educational needs (SEN) to study medicine. It is based primarily on their experience of the studies and on their medical practice. To meet the above objective, a questionnaire survey method has been used. The results of the survey could be concluded with general recommendations: the study of general medicine is fully manageable for students with certain SEN such as slight visual or hearing impairments, specific learning disabilities, and internal diseases, while it is manageable in a limited way for students with physical disability of legs. The study of students with SEN such as severe visual or hearing impairment, locomotor disability of the upper limbs and disability of fine motoric skills and mental illness, will be very difficult and complicated even if the university considerably adapts to these conditions. In the case of students with SEN, making the decision regarding future profession in health care should always be realistic and based on individuals and with respect to their future employability.
\end{abstract}

\section{Keywords}

Special Educational Needs, General Medicine, Paramedical Professions, Questionnaire Survey

\section{Introduction}

The study of general medicine has always been one of the most prestigious and most demanding university studies. The amount of information and skills that must be mastered by the future doctor during the course of the study is constantly increasing. The best secondary school graduates have always been 
enrolled to the study area of General Medicine, however, a high percentage of them do not complete their study (Rosebraugh, 2000). One can just guess, which students do not complete the study because the mismanagement of the actual curriculum and how many of unsuccessful students would have been successful if a required support for students with special educational needs (SEN), due to health impairment or disability, had been provided to them (Kleňhová \& Vojtěch, 2011; Faigel, 1998). In this sense, these special educational needs are further understood in the text.

The process of widening access to students with special educational needs cannot be understood as their prioritizing but as the creation of supportive measures during the study, which will enable them to complete the study in full extent (Zezulková \& Krhutová, 2009) and strengthen their personal autonomy (Krhutová, 2013) and help them to reduce social barriers (Cook, Griffin, Hayden, Hinson, \& Raven, 2012). There are, however, fields of study, where even the maximum degree of adjustment of learning environment does not allow the student to complete all obligations in full extent and thus comply the requirements for the profession performance.

Non-medical healthcare fields and medical professions occupy a special position among other fields of study; there are known as professional fields and their content is strictly defined by legal standards. In the process of equalization of opportunities for college students with special educational needs, the university (institution) has only limited possibility to modify education as strict accreditation requirements and applicable health legislation must be fully met.

The study focuses on the issue in what ways mainly healthy students evaluate opportunities of students with special educational needs to study medicine. It is mainly based on their experience of the studies they have already completed or their medical practice.

\section{Research Method}

The main objective of our survey was to determine how the students of general medicine, evaluate opportunities of students with special educational needs to study general medicine, based on their experience. In order to meet the stated goal, the survey method was chosen, the respondents of the target group were offered the opportunity to answer questions about the given issue. Participation in the survey was voluntary, the students participated in the survey based on their decision (Chráska, 2007).

\subsection{Target Group}

The target groups of the questionnaire survey were students of all years of general medicine at the Ostrava University in Ostrava.

\subsection{Data Collection}

The questionnaire survey was used for data collection. The questionnaire sur- 
veys were realized at the end of the academic year 2013/2014 (Sochorová \& Závacká, 2014) and again in the academic year 2015/1016. During the first questionnaire survey, 370 students of general medicine were addressed through the university e-mails while 418 students were addressed two years later. In the introductory text, students learned the target of the survey and that the participation is voluntary.

The data were collected electronically through an online form, in which respondents selected from the available answers, but they also had an opportunity to add free-text comments.

\subsection{Categories of the Specific Education Needs}

For the purpose of assessing the student's functional abilities in relation to study duties, students with specific needs are divided into categories according to the potential need to modify the study conditions. When creating categories, the methodology of the Ministry of Education Youth and Sports (MEYS) has been used (MEYS, 2014). The methodology distinguishes typology of disabilities for the purposes of financing the increased costs associated with the provision of studies for students with special needs.

For the purposes of the survey, this typology has been modified into the category of students with internal diseases where chronic somatic diseases and mental disorders with regard to psychological demands of the study and profession were separated.

Categorizations of specific needs in our survey are as follows:

(A) Students with vision disabilities.

(A1) Slightly visually impaired students/eyesight users (Students work with common document formats; image editing involves enlarging optical character or other changes).

(A2) Severely visually impaired/touch/voice users (Student work with tactile printed documents or screen readers, requiring editable format text document or content and form adapted document).

(b) Students with hearing impairments.

(b1) Hard of hearing/user of verbal language (student receives information and communicate through verbal language, Czech language).

(B2) Deaf/sign language users (student receives information and communicates through sign language, Czech sign language).

(C) Students with physical disabilities.

(C1) Lower limb disability, paraplegia (for independent movement, students need and use other personal devices, supporting sticks, mechanical or electric wheelchair).

(C2) Students with disabilities of the upper extremities and fine motoric skills (student is not able to perform effectively such tasks as taking notes by hand or on the keyboard, manipulating tools and devices that are necessary for fulfilling all study obligations or manipulation with objects of everyday use). 
(D) Students with specific learning disabilities (dyslexia, dysgraphia, orthography, dyscalculia, dyspraxia).

(E) Student with internal diseases (illness objectively disables the student to fulfil study requirements in a standard way or requires special organizational demands from the school).

(E1) students with chronic somatic diseases.

(E2) students with mental disorder.

\section{The questions of the form}

In the introduction, the respondent was acquainted with the aim of the survey and with specific educational needs. Then it was followed by questions that ascertained all the information concerning the respondent. In the next part, the respondents were asked to express their views according to their experience and answer how the student is able to handle the study of general medicine in each category of specific needs, namely:

- Theoretical part of study usually in the form of monologue or dialogue of the teacher with the student with the support of audio-visual equipment,

- Practical education led at school, at school laboratories takes place in specialized classrooms and is usually implemented through practical exercises where students practice their skills on each other or simulation models or special software support are used,

- Guided and individual practice where students improve their skills under the supervision of a mentor or in the case of individual practice under the supervision of a contact person responsible,

- Clinical placement in medical institutions, bedside students. Students apply their knowledge and skills in the contact with patients under the supervision of the guarantor of practical training.

The chosen classification into four main units affects main teaching methods. Each of the four sections has a different nature regarding the way of study obligations fulfilment and, therefore, there was assessed separately. The last two units in the survey were optional, because not all of the students involved in the survey had previously completed all four units. To record the answers, students selected boxes arranged in a grid (Figure 1).

\subsection{Characteristics of Respondents}

A total of 83 respondents completed the survey, i.e. $10.5 \%$ of the total number of respondents, where 69 respondents participated the survey for the first time and 14 respondents repeatedly. A total of 47 women and 22 men from the total number of respondents participated in the first survey that corresponds to the ratio of surveyed students. In the second survey, the answers of 14 students who participated in the initial investigation were there collected and analyzed independently, see below.

Distribution of respondents according to the year of study is shown in Figure

2. The smallest number of respondents was from the last sixth year of study, 
Theoretical part of the study*

Based on your experience with the study you have already completed and based on the information gained from the introductory information in the survey please consider how a student with different types of special needs would master this activity in your opinion

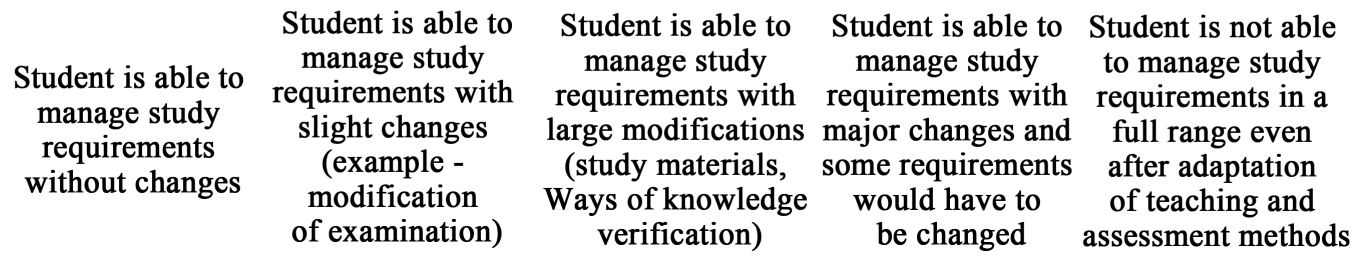

\begin{tabular}{|c|c|c|c|c|c|}
\hline $\begin{array}{l}\text { Slightly visually } \\
\text { impaired/eyesight } \\
\text { user }\end{array}$ & 0 & 0 & 0 & 0 & 0 \\
\hline $\begin{array}{l}\text { Seriously visually } \\
\text { impaired / voice } \\
\text { and touch users }\end{array}$ & 0 & 0 & 0 & 0 & 0 \\
\hline $\begin{array}{l}\text { Hard hearing } \\
\text { person / user of } \\
\text { verbal language }\end{array}$ & 0 & 0 & 0 & 0 & 0 \\
\hline $\begin{array}{l}\text { Deaf / user of } \\
\text { sign language }\end{array}$ & 0 & 0 & 0 & 0 & 0 \\
\hline $\begin{array}{l}\text { People with lower } \\
\text { limb disabilities }\end{array}$ & 0 & 0 & 0 & 0 & 0 \\
\hline $\begin{array}{l}\text { People with } \\
\text { disabilities of the } \\
\text { upper extremities, } \\
\text { fine motor skills }\end{array}$ & 0 & 0 & 0 & 0 & 0 \\
\hline $\begin{array}{l}\text { People with } \\
\text { specific learning } \\
\text { disabilities }\end{array}$ & 0 & 0 & 0 & 0 & 0 \\
\hline $\begin{array}{l}\text { People with } \\
\text { chronic } \\
\text { somatic diseases }\end{array}$ & 0 & 0 & 0 & 0 & 0 \\
\hline $\begin{array}{l}\text { People with } \\
\text { mental disorder }\end{array}$ & 0 & 0 & 0 & 0 & 0 \\
\hline
\end{tabular}

Figure 1. Poll grid to fill opinions of students on mastering theoretical part of the study.

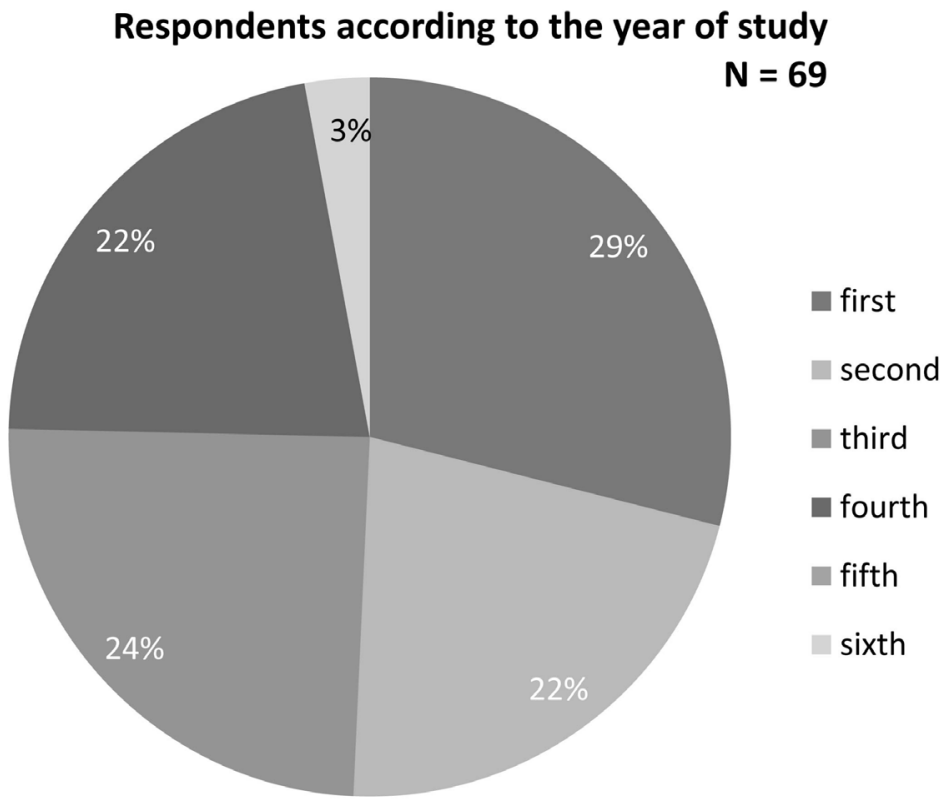

Figure 2. Respondents according to their year of study. 
which is due to the fact that in this year students participate in their clinical internships outside the faculty. Survey questions focused on clinical, guided and individual practices that are the part of the curriculum of higher years of studies, were answered by 24 students (in the third and fourth year of study). Six students out of the total number of respondents were students with special educational needs.

\section{Results of the Survey}

Outcomes of the survey can be presented from two perspectives by categorizing specific educational needs or by division into units according crucial methods of teaching (theory, practical instruction, clinical internship, practical placement). In terms of career decisions for applicants with special educational needs, the first option will be used, and according to various categories of students with special educational needs, it is shown which crucial part of instruction, according to respondents' opinions, could be a major obstacle to successful completion of the study.

\subsection{Visual Impairment}

Student typology A1 (light visual impairment), according to the above typology, works with common document formats and adjustment of image is based on the enlargement of the images and other optical changes The results show that light visual impairment is not considered a major obstacle to manage the study of general medicine, only 2 respondents out the total of 69 students take the view that this type of special needs would be a barrier to complete the practical instruction conducted at school (work laboratory, etc.). The reason could be the fact that within the first three years of study curriculum, practical subjects that require working with a microscope and simulation of processes via PC are included.

Completely different situation arises in the case of a student with severe visual impairment, who works with tactile printed documents or screen readers and requires an editable text document format, and content and form adapted documents if necessary. These results are presented in Figure 3, the majority of students considers unrealistic to complete required lessons in the full extent even when the learning materials, teaching and evaluation methods are modified.

\subsection{Hearing Impairment}

The opinions of respondents concerning students with a hearing impairment B1 are similar to those of students with mild visual impairment that is illustrated in the diagram, where visually dominates light areas, a view that the student with such a kind of disability is able to manage the studies without modification or with some occasional modifications, as confirmed by a particular situation at the Faculty of Medicine.

For a student with a hearing impairment typology B2 (deaf/sign language 


\section{A. Students with vision disabilities - A2. Severely visually impaired/touch/voice users}

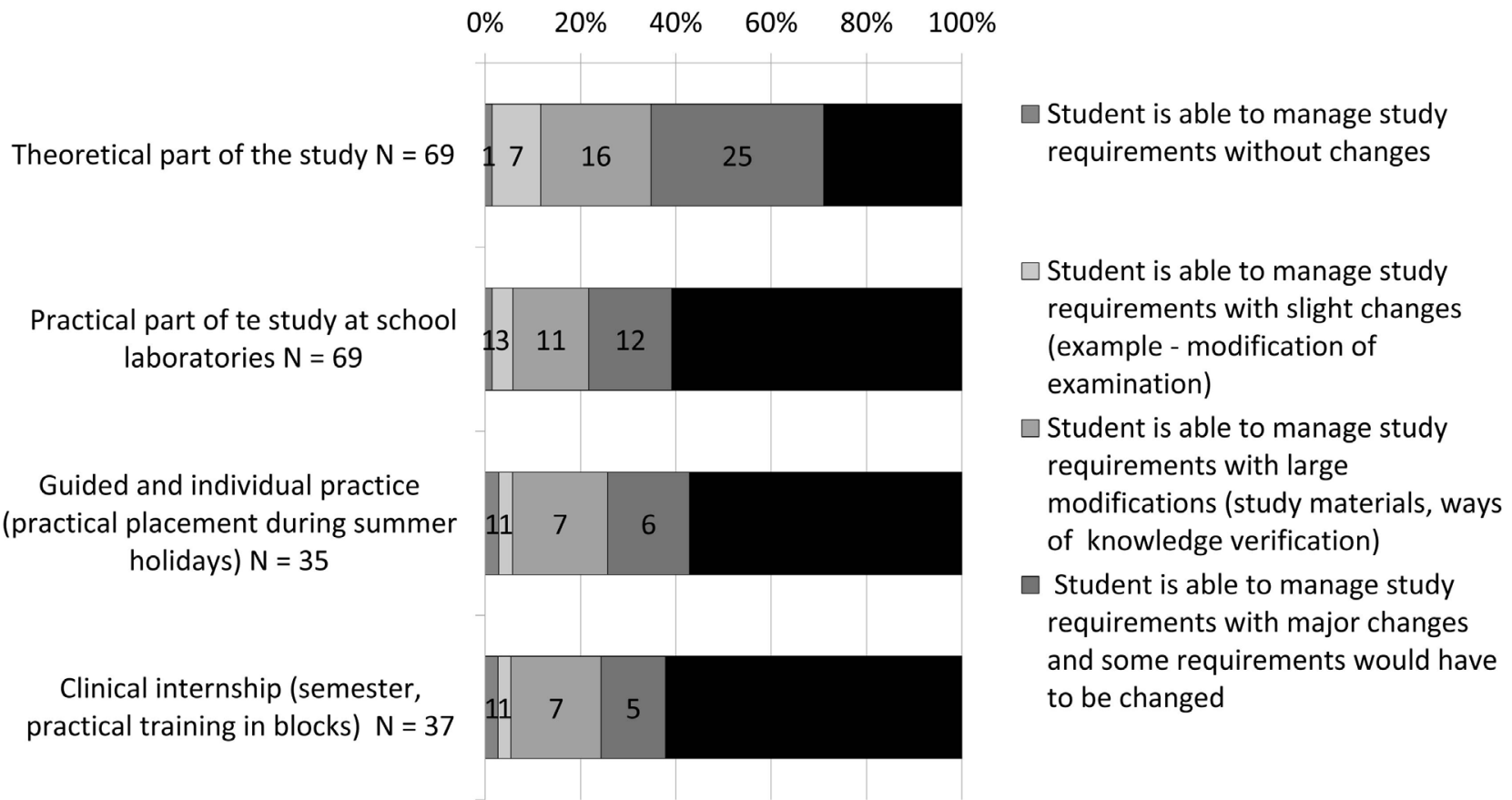

Figure 3. The degree of management of study obligations of a student with typology A2 (severely visually impaired).

users), it will be very difficult to manage all the study obligations even if possible modifications are used. As shown in Figure 4, 15 respondents from 37 considers unrealistic for such students to master fundamental part of practical training, clinical internships and guided practice, and 11 respondents consider these learning units to be manageable only in the case of significant modifications, which could be very difficult with regard to above mentioned mandatory standards. It should be kept in mind that a doctor must be able to communicate with patients, and it could be a fundamental problem in this profession, a communication barrier between a doctor and a patient could affect the speed while determining diagnoses and appropriate treatment. Nevertheless respondents can see complications to manage the curriculum at school courses (theory and practice).

\subsection{Physically Handicapped}

Also respondents' views on managing the course requirements by students with physical disabilities, with lower limb disabilities, paraplegia (for independent movement they need and use other personal devices, supporting sticks, mechanical or electric wheelchair) were assessed. Respondents do not evaluate positively the possibility of managing practical courses, although it must be noted that, especially in this case, it strongly depends on the degree of disadvantage.

Students with disabilities of the upper extremities and fine motoric skills (C2 typology) are not able to perform effectively e.g. taking notes by hand, if necessary on the keyboard, manipulate objects and devices that are necessary to fulfill study obligations, then, in the opinion of respondents such student will not 


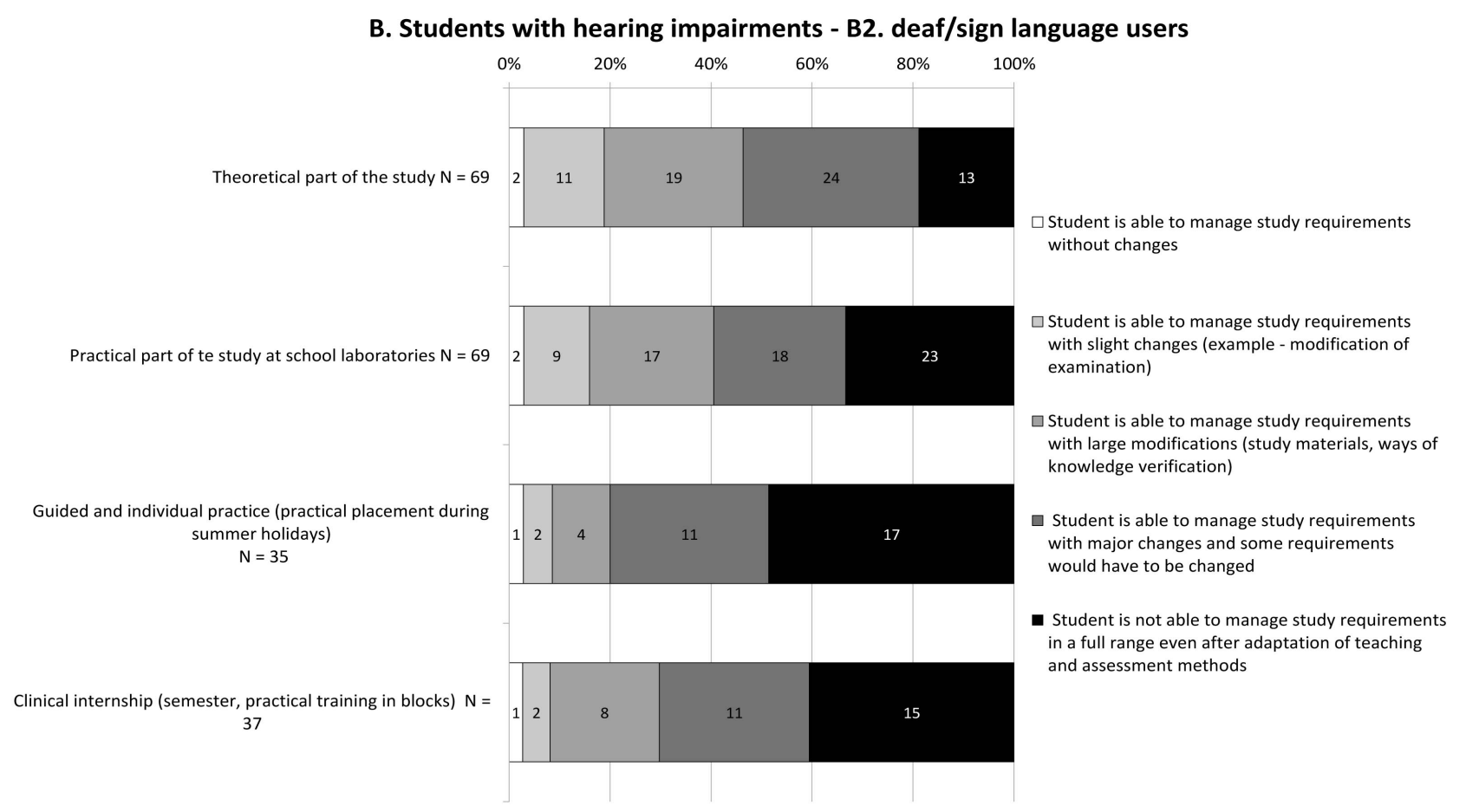

Figure 4. The degree of management of study obligations of a student with typology B2.

be able to handle the theoretical part of instruction even at maximum possible adaptation. In Figure 5 presenting these opinions, prevailing dark fields (such student is not able to complete some obligations in full range and some obligations would need to be eventually changed) in all four learning units can be seen.

\subsection{Students with Specific Learning Disabilities}

Respondents' opinions on fact how a student with a specific learning disabilities (typology D) will handle obligations arising from study plan are presented in Figure 6. From the outside view, the most difficult for such students seems to be completing the theoretical part of instruction. However, previous experience with the students of general medicine at the Faculty of Medicine of University of Ostrava indicate that in this case the handicap was significantly outweighed by a high motivation and diligence and those students were most successful ones. This fact was, in the case of students with dyslexia, also confirmed by international studies (McKendree \& Snowling, 2011).

\subsection{Students with Internal Diseases}

For the purpose of the present observational study, the type of specific needs in category $\mathrm{E}$ (student with an internal disease) was split into two separate subtypes. Insight into the results presented in Figure 7 and Figure 8 shows that this division has its own justification. Figure 7 presents the views of respondents on mastering the study requirements in the case of students with special educational needs suffering chronic somatic diseases while Figure 8, presents the views on students suffering mental disorders. 


\section{Students with physical disabilities}

C2. Students with disabilities of the upper extremities and fine motoric skills

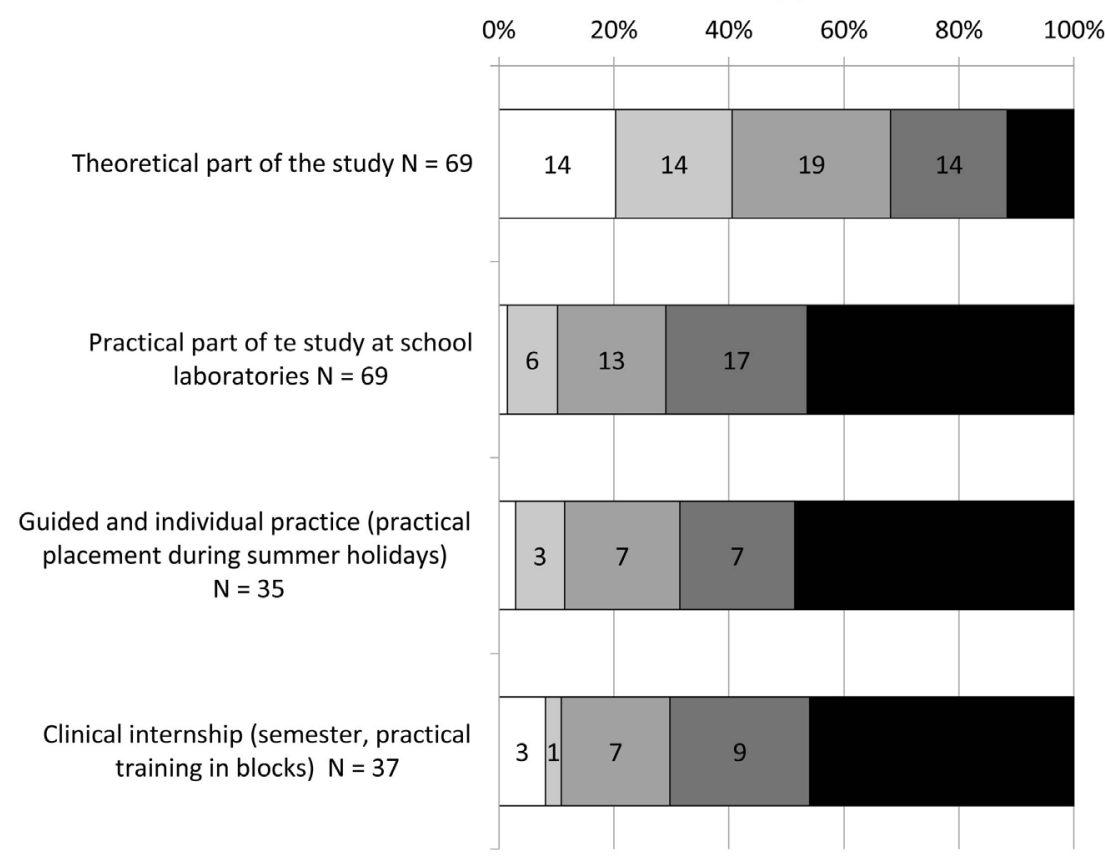

$\square$ Student is able to manage study requirements without changes

$\square$ Student is able to manage study requirements with slight changes (example - modification of examination)

$\square$ Student is able to manage study requirements with large modifications (study materials, ways of knowledge verification)

$\square$ Student is able to manage study requirements with major changes and some requirements would have to be changed

Student is not able to manage study requirements in a full range even after adaptation of teaching and assessment methods

Figure 5. The degree of management of study obligations of a student with typology C2.

\section{Students with specific learning disabilities}

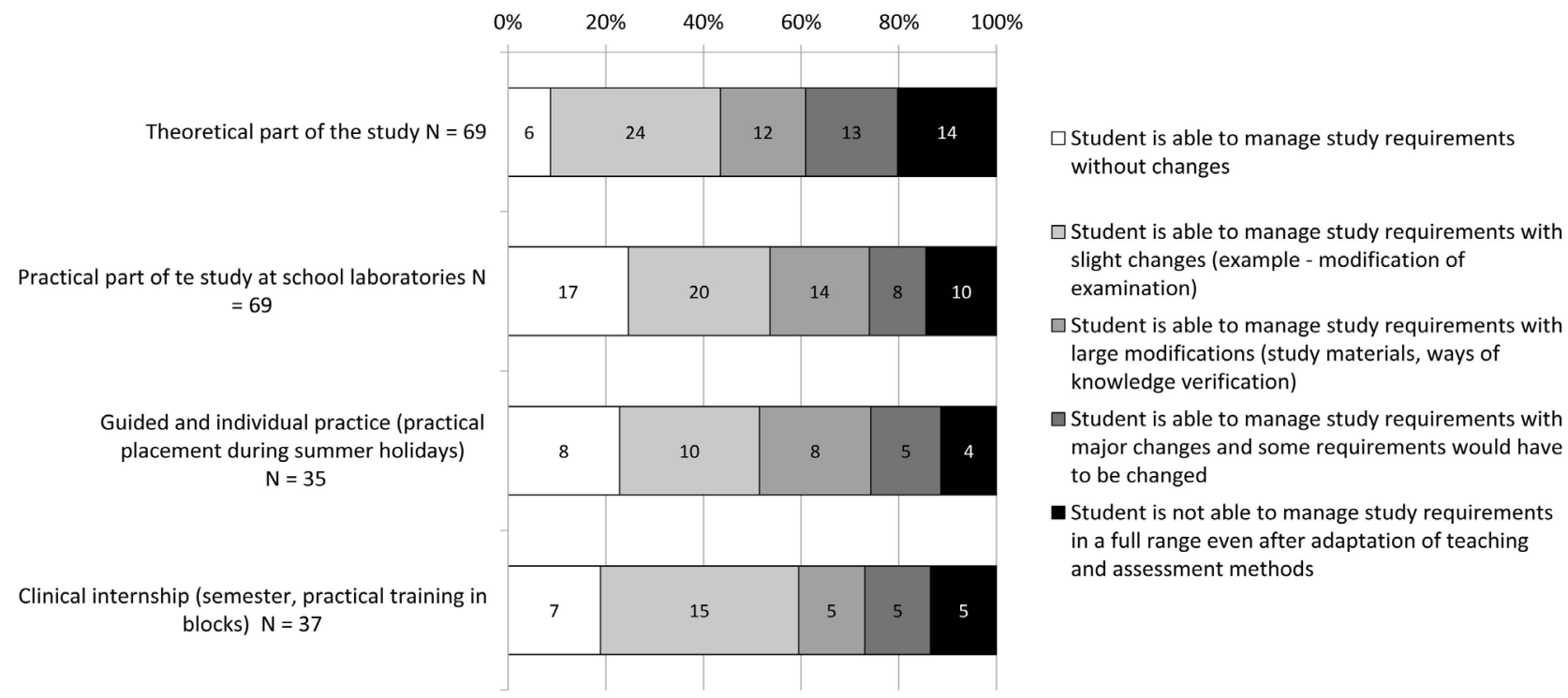

Figure 6. The degree of management of study obligations of a student with typology D.

In the comparison of the two images No. 7 and 8, at first sight, there is a distinct difference in the "detriment" of students with specific needs based on mental disorders. In this case, a high percentage of respondents in all learning units consider that such a student will not be able to fulfill study requirements with regard to a large degree of psychological stress, as the demands on the knowledge and skills of future physicians are very high. 


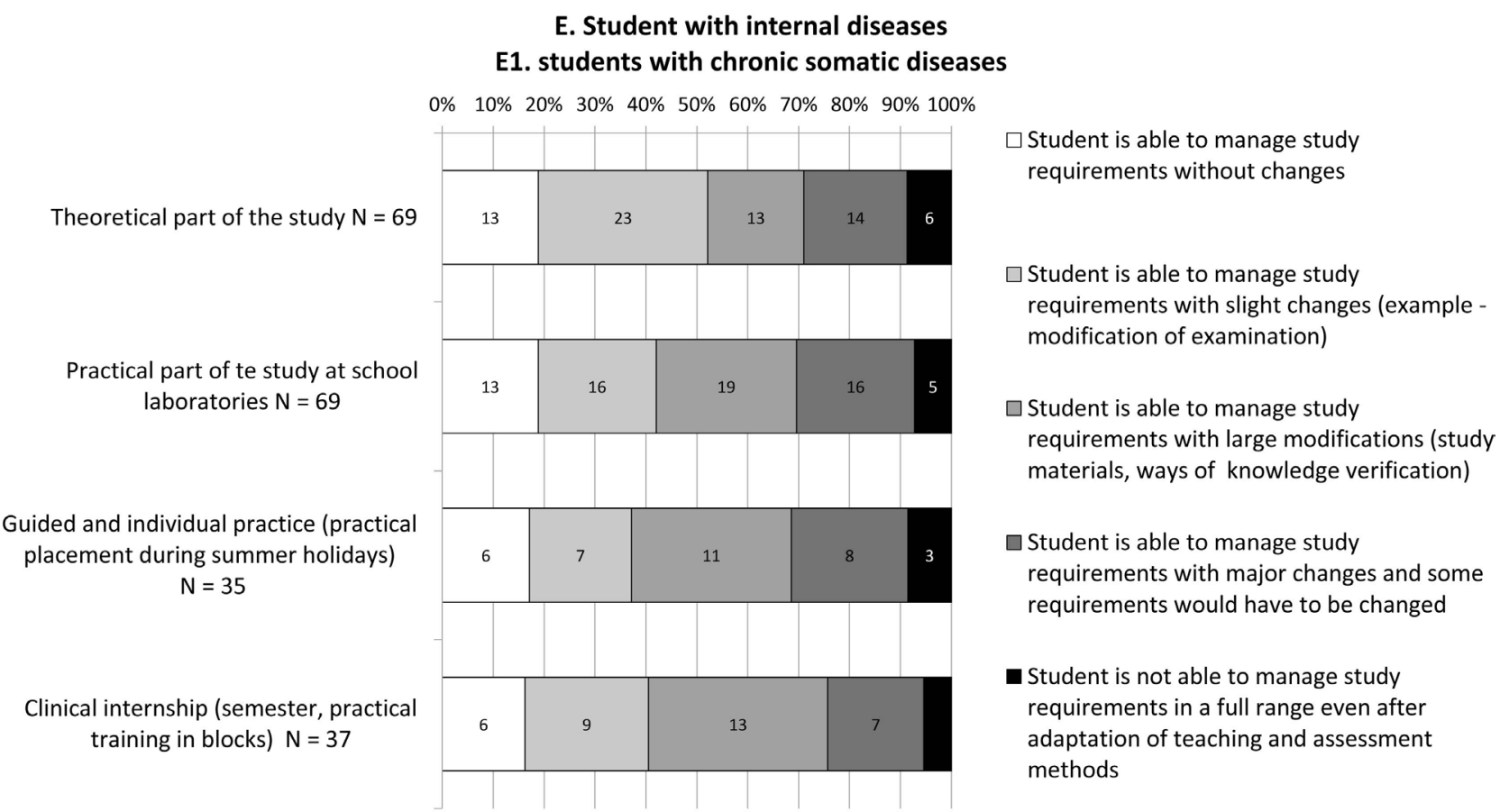

Figure 7. The degree of management of study obligations of a student with typology E1.

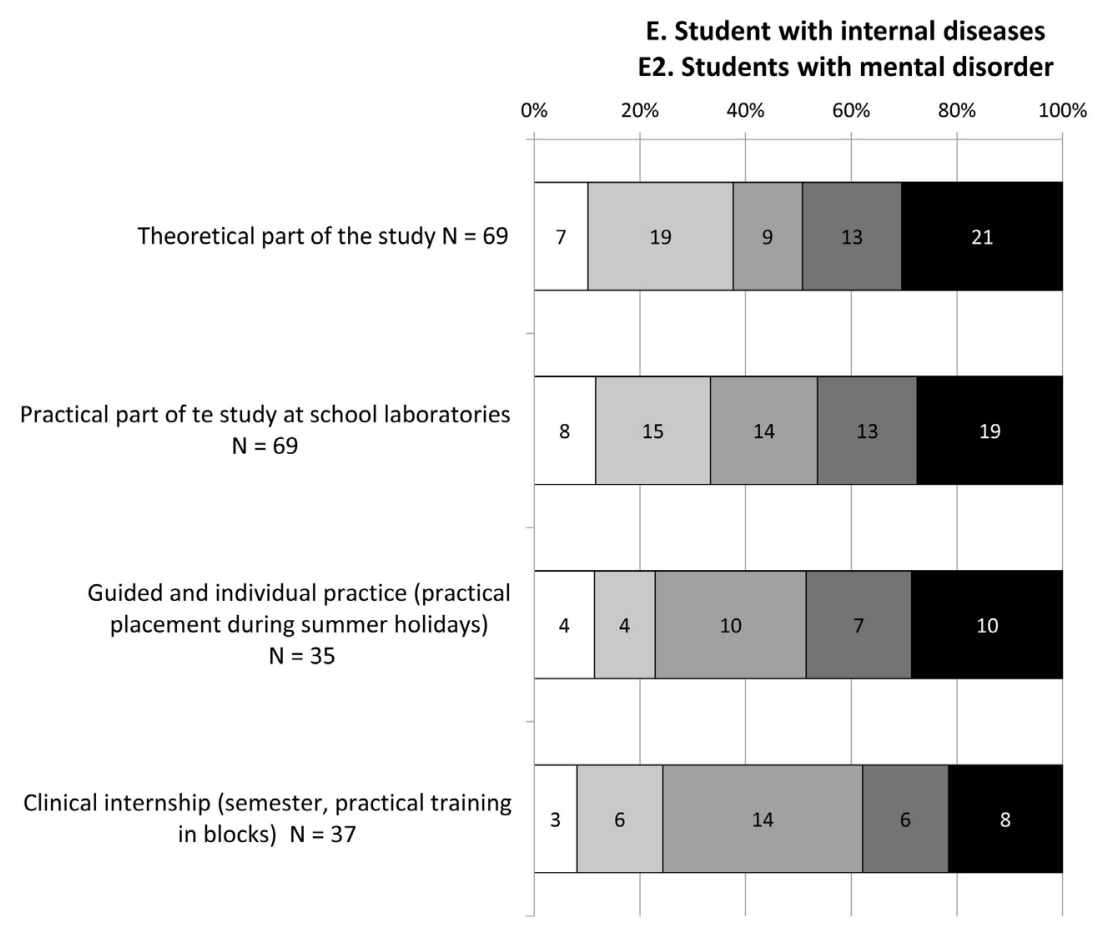
$\square$ Student is able to manage study requirements without changes

$\square$ Student is able to manage study requirements with slight changes (example - modification of examination)

$\square$ Student is able to manage study requirements with large modifications (study materials, ways of knowledge verification)

$\square$ Student is able to manage study requirements with major changes and some requirements would have to be changed

- Student is not able to manage study requirements in a full range even after adaptation of teaching and assessment methods

Figure 8. The degree of management of study obligations of a student with typology E2.

\section{The Development of Respondents' Opinions during the Study}

Due to the fact that the survey was carried out in two waves, some respondents participated repeatedly. These outcomes were evaluated separately and com- 
pared with the outputs of the first survey. It turns out that during the course of medical studies (in two years' interval), there was a slight shift in opinions on this issue, as shown in Figure 9 and Figure 10.

Figure 9 shows the shift in opinions of students on mastering theoretical part of instruction. You cannot clearly say in which direction has the opinion shifted. For various types of specific needs, shift varies. For example, in the category with a slight visual impairment or motoric disability of lower limbs, a shift in favor of management of study obligation has been detected while a different shift has been detected in the case of disability of upper limbs and severe visual impairment where the opinions incline more to the inability of mastering the curriculum in its full range. Figure 10 shows a similar comparison for clinical practice.

In 2013, a similar poll survey was carried out, where the target group consisted of students studying in fields of paramedical professions in all grades and forms of study at the Faculty of Medicine of University of Ostrava (Sochorová \& Závacká, 2013).

There were contacted 1005 students, 164 of whom were involved in the survey. Those students represented $16.3 \%$ of the addressed students (18 men, 146

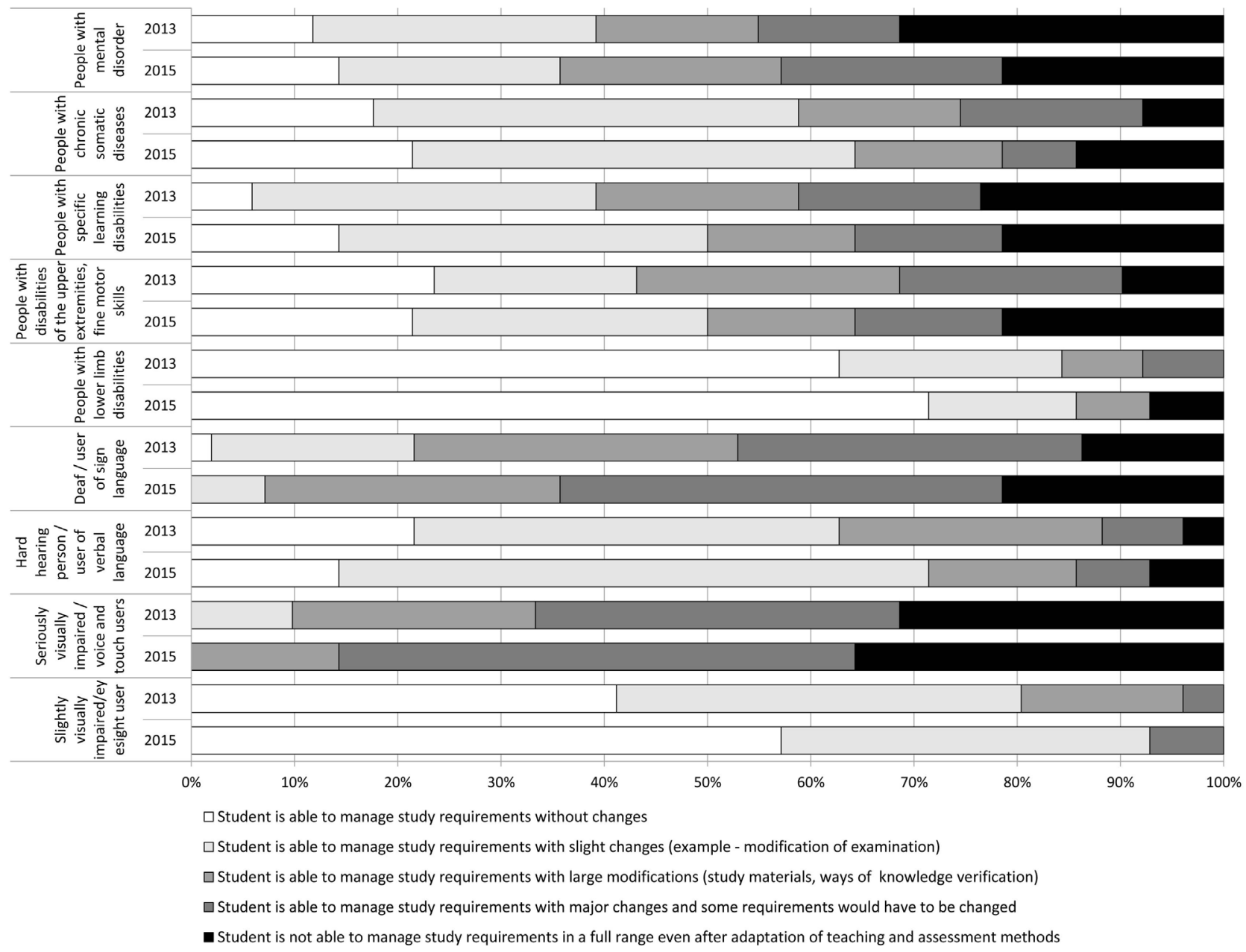

Figure 9. Shift opinion during the study, the theoretical part of the study. 


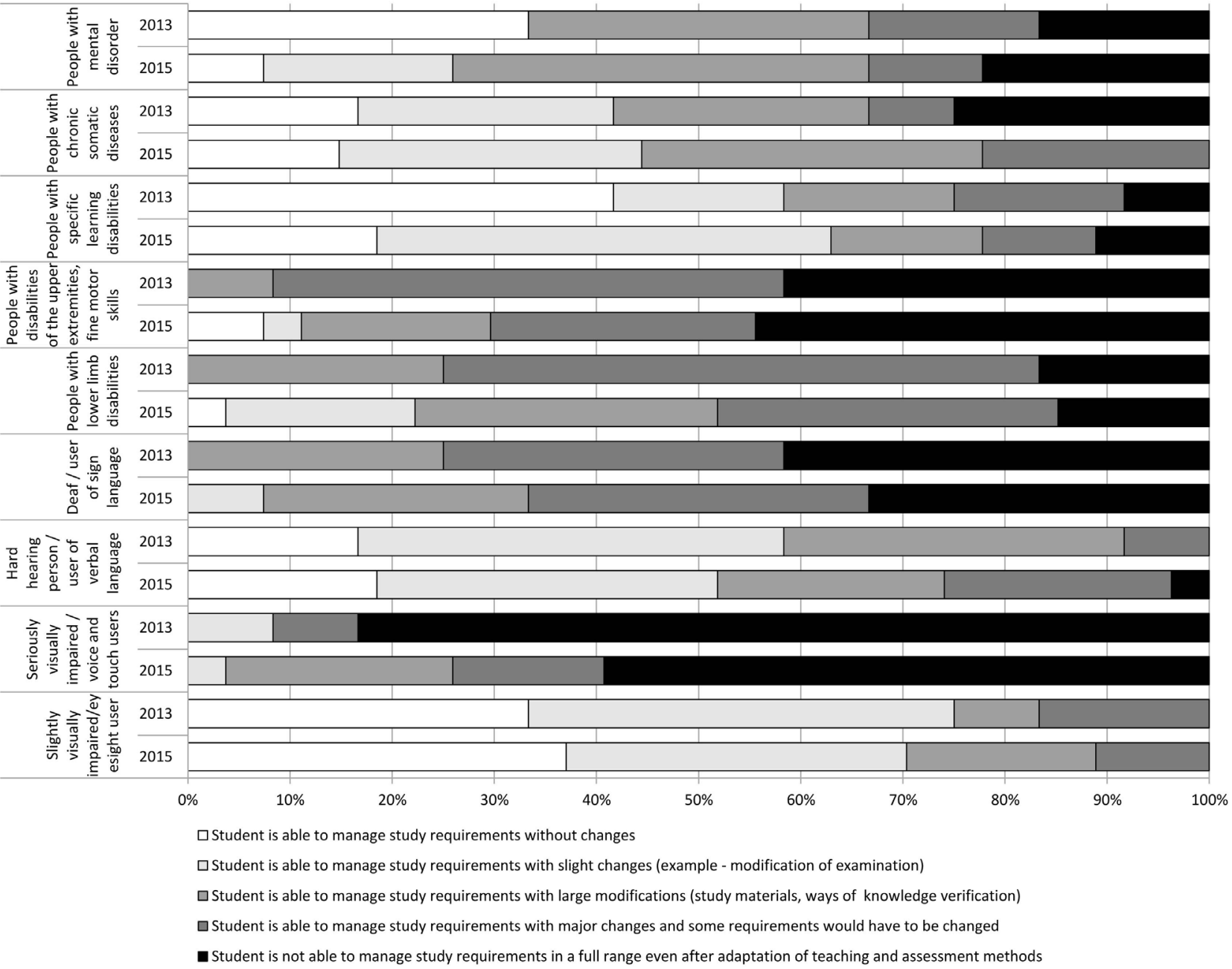

Figure 10. Shift in opinion during the study—clinical internships.

women) that is about $3 \%$ more than the total number of respondents among students of medicine. In the study there were included students from all the study fields, types and years of the study. The poll was conceived in a similar way, the core part of the questionnaire consisted of questions in which respondents considered if the student with specific needs would be able to handle study duties. These duties were divided into four separate areas-the theoretical part of teaching and three different ways of practical teaching-in the view of the prevailing teaching methods.

Respondents considered that the least difficult would be to master theoretical instruction mainly for students with a low visual impairment and motor impairment of the lower limbs. Mastering studies with great support and modified teaching methods were attributed to students with severe visual and hearing impairments. On the other hand, 41 respondents (25\%) considered psychological disorder to be a major barrier to master theoretical instruction.

When assessing teaching in school laboratories (students do not come in direct contact with the patient, mostly use models and trainers and train the rou- 
tine skills) the smallest problem was seen among students with light vision impairment, 42 respondents i.e. $25.6 \%$. Than in students with a slight hearing impairment, where $11.6 \%$ of respondents expects problems. On the other hand, the greatest difficulty in mastering the basic practical activities was seen among respondents with motor disorders. $50 \%$ of respondents are of the opinion that a student with this disability is not able to complete most of the practical lessons. This handicap is a major barrier especially in mastering manual skills (health technician, physiotherapist and others).

After practicing basic skills in school laboratories and models, students of non-medical professions continue to practice their studies directly in the health facility. The teacher or the mentor is still present in the classroom, and the student is under constant supervision. In this part of the course, the student is involved in regular medical care, and in most fields there is direct contact with patients. In all categories of specific needs, here significantly increased the number of respondents, who believe that a student with specific educational needs is unable to handle the training. Similar results were detected in the case of upper extremity and soft motor skills impairment, which were found to be the biggest problems according to the respondents. It was followed with severe visual and hearing impairment, lower limb disorder and mental disorders. 12 respondents (7\%) believed that even a visually impaired student would not be able to complete all practical exercises. For example, in the physiotherapist's profession, the primary examination of the patient is based on a visual evaluation of the condition and any visual impairment makes this initial examination more difficult.

Further degree of practical instruction is a continuous individual practice. It usually occurs during holiday periods when the student is fully involved in the activities that take place in a health facility. Students usually seek such facility at their hometowns. Here, the student has to demonstrate almost full professional knowledge and ability to work independently, in accordance with Act No. 105/2011 Coll., On conditions for acquiring and recognizing competence to perform non-medical healthcare professions and performing activities related to providing health care, as amended, to perform a profession without professional supervision. Similarly as in previous types of practice, respondents saw the greatest complications in students with upper limb disabilities, motor impairment, and students with severe visual impairment. On the contrary, the smallest complications were seen in students with a slight visual or auditory disability, 38 respondents (23\%) assumed that the student was able to complete the practice in case of light visual impairment.

The following tables summarize and compare outcomes from the field of inquiry surveys. They compare students' views on the management of study duties in the fields of non-medical field and general medicine. Students with specific needs are divided into categories $\mathrm{A}$ to $\mathrm{E}$ for the purpose of comparing both poll surveys according to the used typology, category D in the 2013 survey for non-medical fields of study was not used. Always the two highest values are highlighted in bold. 
Table 1 compares the individual teaching units (there are always four theoretical parts of the general and non-medical branches, the theoretical and practical lessons at school at the same) in the situation when the respondents expressed the opinion that the student would be able to handle the duties without modification or only with small modifications, such as modification of the test method. From the table it is clear that the outcomes of the surveys are similar, where the highest percentage of respondents leaning towards specific learning needs based on light visual impairment, light hearing impairment, and specific learning disorders (general medicine only).

Table 1. Summary table of assessment of the manageability of lessons without modification or less modification from the point of view of students, comparison of the study of general medicine and non-medical fields according to the nature of the teaching methods.

\begin{tabular}{|c|c|c|c|c|c|}
\hline & \multirow[b]{2}{*}{$\begin{array}{l}\text { Student is not able to manage study } \\
\text { requirements without or with slight changes }\end{array}$} & \multicolumn{4}{|c|}{ General Medicine } \\
\hline & & $\begin{array}{l}\text { Theoretical } \\
\text { part of the } \\
\text { study } \\
\mathrm{N}=51\end{array}$ & $\begin{array}{l}\text { Practical of the } \\
\text { study at school } \\
\text { laboratories } \\
\mathrm{N}=51\end{array}$ & $\begin{array}{l}\text { Guided and individual } \\
\text { practice (Practical } \\
\text { placement during } \\
\text { summer holidays) } \\
\mathrm{N}=24\end{array}$ & $\begin{array}{c}\text { Clinical Internship } \\
\text { (semester, practical } \\
\text { training in blocks) } \\
\mathrm{N}=24\end{array}$ \\
\hline A1 & Slightly visually impaired/eyesight user & $80.4 \%$ & $51.0 \%$ & $70.8 \%$ & $79.2 \%$ \\
\hline A2 & Seriously visually impaired/voice and touch users & $9.8 \%$ & $5.9 \%$ & $4.2 \%$ & $4.2 \%$ \\
\hline B1 & Hard hearing person/user of verbal language & $62.7 \%$ & $52.9 \%$ & $45.8 \%$ & $58.3 \%$ \\
\hline B2 & Deaf/user of sign language & $21.6 \%$ & $2.0 \%$ & $8.3 \%$ & $8.3 \%$ \\
\hline $\mathrm{C} 1$ & People with lower limb disabilities & $84.3 \%$ & $15.7 \%$ & $12.5 \%$ & $25.0 \%$ \\
\hline $\mathrm{C} 2$ & $\begin{array}{l}\text { People with disabilities of the } \\
\text { upper extremities. fine motor skills }\end{array}$ & $43.1 \%$ & $0.0 \%$ & $12.5 \%$ & $25.0 \%$ \\
\hline $\mathrm{D}$ & People with specific learning disabilities & $39.2 \%$ & $51.0 \%$ & $54.2 \%$ & $70.8 \%$ \\
\hline E1 & People with chronic somatic diseases & $58.8 \%$ & $43.1 \%$ & $45.8 \%$ & $50.0 \%$ \\
\hline \multirow[t]{3}{*}{ E2 } & People with mental disorder & $39.2 \%$ & $35.3 \%$ & $29.2 \%$ & $29.2 \%$ \\
\hline & & \multicolumn{4}{|c|}{ Paramedical Profession } \\
\hline & & $\begin{array}{l}\text { Theoretical } \\
\text { part of the } \\
\text { study } \mathrm{N}=164\end{array}$ & $\begin{array}{l}\text { Practical of the } \\
\text { study at school } \\
\text { laboratories } \\
\mathrm{N}=164\end{array}$ & $\begin{array}{c}\text { Guided and } \\
\text { practice (in a } \\
\text { health care } \\
\text { institution) } \mathrm{N}=164\end{array}$ & $\begin{array}{c}\text { Individual } \\
\text { Continuous } \\
\text { Practice N = } 164\end{array}$ \\
\hline A1 & Slightly visually impaired/eyesight user & $75.0 \%$ & $65.9 \%$ & $60.4 \%$ & $59.1 \%$ \\
\hline A2 & Seriously visually impaired/voice and touch users & $9.8 \%$ & $9.1 \%$ & $5.5 \%$ & $6.1 \%$ \\
\hline B1 & Hard hearing person/user of verbal language & $36.6 \%$ & $39.6 \%$ & $31.1 \%$ & $31.1 \%$ \\
\hline B2 & Deaf/user of sign language & $10.4 \%$ & $10.4 \%$ & $4.3 \%$ & $5.5 \%$ \\
\hline $\mathrm{C} 1$ & People with lower limb disabilities & $68.3 \%$ & $23.8 \%$ & $11.6 \%$ & $13.4 \%$ \\
\hline $\mathrm{C} 2$ & $\begin{array}{l}\text { People with disabilities of the } \\
\text { upper extremities, fine motor skills }\end{array}$ & $44.5 \%$ & $9.8 \%$ & $5.5 \%$ & $7.9 \%$ \\
\hline $\mathrm{D}$ & People with specific learning disabilities & \multicolumn{4}{|c|}{$\mathrm{xxx}$} \\
\hline E1 & People with chronic somatic diseases & $37.8 \%$ & $39.6 \%$ & $26.8 \%$ & $25.6 \%$ \\
\hline E2 & People with mental disorder & $32.9 \%$ & $30.5 \%$ & $20.7 \%$ & $19.5 \%$ \\
\hline
\end{tabular}


Table 2, on the other hand, shows which specific educational needs, in the opinion of the respondents, would probably be the reason for not meeting full-time study requirements. Even here the comparison of the study of general medicine and paramedical professions is similar the highest percentage of respondents considered unrealistic to fulfill study duties in the case of specific educational needs based on severe visual impairment, fine motor impairment and psychological illness.

Table 3 and Table 4 then present the results collectively for all four units on average (i.e., how many percent of respondents consider all study duties for a given category of specific needs to be manageable/unmanageable).

Table 2. Summary table of full-time exclusion assessment, comparison of general medicine and non-medical fields by the nature of teaching methods.

\begin{tabular}{|c|c|c|c|c|c|}
\hline & \multirow[b]{2}{*}{$\begin{array}{l}\text { Student is not able to manage study } \\
\text { requirements in a full range even after } \\
\text { daptation of teaching and assessment methods }\end{array}$} & \multicolumn{4}{|c|}{ General medicine } \\
\hline & & $\begin{array}{l}\text { Theoretical } \\
\text { part of the } \\
\text { study } \mathrm{N}=51\end{array}$ & $\begin{array}{l}\text { Practical of the } \\
\text { study at school } \\
\text { laboratories } \\
\mathrm{N}=51\end{array}$ & $\begin{array}{c}\text { Guided and } \\
\text { individual practice } \\
\text { (Practical placement } \\
\text { during summer } \\
\text { holidays) } \mathrm{N}=24\end{array}$ & $\begin{array}{l}\text { Clinical internship } \\
\text { (semester, } \\
\text { practical training } \\
\text { in blocks) } \mathrm{N}=24\end{array}$ \\
\hline A1 & Slightly visually impaired/eyesight user & $0.0 \%$ & $3.9 \%$ & $0.0 \%$ & $0.0 \%$ \\
\hline A2 & Seriously visually impaired/voice and touch users & $31.4 \%$ & $60.8 \%$ & $50.0 \%$ & $66.7 \%$ \\
\hline B1 & Hard hearing person/user of verbal language & $3.9 \%$ & $9.8 \%$ & $4.2 \%$ & $4.2 \%$ \\
\hline B2 & Deaf/user of sign language & $13.7 \%$ & $31.4 \%$ & $37.5 \%$ & $37.5 \%$ \\
\hline $\mathrm{C} 1$ & People with lower limb disabilities & $0.0 \%$ & $5.9 \%$ & $33.3 \%$ & $16.7 \%$ \\
\hline $\mathrm{C} 2$ & $\begin{array}{l}\text { People with disabilities of the } \\
\text { upper extremities. fine motor skills }\end{array}$ & $9.8 \%$ & $45.1 \%$ & $41.7 \%$ & $50.0 \%$ \\
\hline $\mathrm{D}$ & People with specific learning disabilities & $23.5 \%$ & $17.6 \%$ & $8.3 \%$ & $12.5 \%$ \\
\hline E1 & People with chronic somatic diseases & $7.8 \%$ & $5.9 \%$ & $4.2 \%$ & $0.0 \%$ \\
\hline \multirow[t]{3}{*}{ E2 } & People with mental disorder & $31.4 \%$ & $25.5 \%$ & $29.2 \%$ & $25.0 \%$ \\
\hline & & \multicolumn{4}{|c|}{ Paramedical profession } \\
\hline & & $\begin{array}{l}\text { Theoretical part } \\
\text { of the study } \\
\mathrm{N}=164\end{array}$ & $\begin{array}{l}\text { Practical of the } \\
\text { study at school } \\
\text { laboratories } \\
\mathrm{N}=164\end{array}$ & $\begin{array}{l}\text { Guided and } \\
\text { practice (in a health } \\
\text { care institution) } \\
\mathrm{N}=164\end{array}$ & $\begin{array}{c}\text { Individual } \\
\text { Continuous } \\
\text { Practice } N=164\end{array}$ \\
\hline A1 & Slightly visually impaired/eyesight user & $1.8 \%$ & $1.8 \%$ & $7.3 \%$ & $7.9 \%$ \\
\hline A2 & Seriously visually impaired/voice and touch users & $11.6 \%$ & $35.4 \%$ & $56.7 \%$ & $57.3 \%$ \\
\hline B1 & Hard hearing person/user of verbal language & $4.9 \%$ & $6.7 \%$ & $18.9 \%$ & $20.1 \%$ \\
\hline B2 & Deaf/user of sign language & $20.1 \%$ & $25.0 \%$ & $48.8 \%$ & $54.3 \%$ \\
\hline $\mathrm{C} 1$ & People with lower limb disabilities & $6.7 \%$ & $25.6 \%$ & $48.8 \%$ & $50.6 \%$ \\
\hline $\mathrm{C} 2$ & $\begin{array}{l}\text { People with disabilities of the } \\
\text { upper extremities, fine motor skills }\end{array}$ & $14.6 \%$ & $50.0 \%$ & $66.5 \%$ & $64.6 \%$ \\
\hline $\mathrm{D}$ & People with specific learning disabilities & \multicolumn{4}{|c|}{$\mathrm{xxx}$} \\
\hline E1 & People with chronic somatic diseases & $6.1 \%$ & $12.2 \%$ & $19.5 \%$ & $23.8 \%$ \\
\hline E2 & People with mental disorder & $25.0 \%$ & $26.8 \%$ & $37.8 \%$ & $39.0 \%$ \\
\hline
\end{tabular}


Table 3 and Table 4 clearly show that although the percentages differ, the highest values in both cases are the same. Divergence can be found in Table 3 for the category of B2 specific needs (sign language use) where respondents expect lower percentage of mastering study duties in non-medical professions, which is probably due to the higher need for direct communication with the patient. In Table 4, this difference was also shown for category B1 (hearing-impaired) here is the percentage of respondents with the view that study is not manageable, more than twice as high. A significantly high percentage of non-medical respondents also exclude full-time studies in the category of

Table 3. Compilation table of assessment of the manageability of lessons without modification or less modification from the point of view of students Comparison of study of general medicine and non-medical fields.

\begin{tabular}{|c|c|c|c|}
\hline & $\begin{array}{l}\text { All learning activities on average } \\
\text { (Student is not able to manage study } \\
\text { requirements in a full range) }\end{array}$ & $\begin{array}{l}\text { General } \\
\text { Medicine }\end{array}$ & $\begin{array}{l}\text { Paramedical } \\
\text { Professions }\end{array}$ \\
\hline A1 & Slightly visually impaired/eyesight user & $70.3 \%$ & $65.1 \%$ \\
\hline A2 & Seriously visually impaired/voice and touch users & $6.0 \%$ & $7.6 \%$ \\
\hline B1 & Hard hearing person/user of verbal language & $55.0 \%$ & $34.6 \%$ \\
\hline B2 & Deaf/user of sign language & $10.0 \%$ & $7.6 \%$ \\
\hline $\mathrm{C} 1$ & People with lower limb disabilities & $34.4 \%$ & $29.3 \%$ \\
\hline $\mathrm{C} 2$ & $\begin{array}{l}\text { People with disabilities of the } \\
\text { upper extremities, fine motor skills }\end{array}$ & $34.4 \%$ & $29.3 \%$ \\
\hline $\mathrm{D}$ & People with specific learning disabilities & $53.8 \%$ & \\
\hline E1 & People with chronic somatic diseases & $49.4 \%$ & $32.5 \%$ \\
\hline E2 & People with mental disorder & $33.2 \%$ & $25.9 \%$ \\
\hline
\end{tabular}

Table 4. Summary table of full-time exclusion assessment comparison of general medical and paramedical studies.

\begin{tabular}{|c|c|c|c|}
\hline & $\begin{array}{l}\text { All learing activities on average } \\
\text { (Student is not able to manage study } \\
\text { requirements in a full range) }\end{array}$ & $\begin{array}{l}\text { General } \\
\text { Medicine }\end{array}$ & $\begin{array}{r}\text { Paramedical } \\
\text { Professions }\end{array}$ \\
\hline A1 & Slightly visually impaired/eyesight user & $1.0 \%$ & $4.7 \%$ \\
\hline A2 & Seriously visually impaired/voice and touch users & $52.2 \%$ & $40.2 \%$ \\
\hline B1 & Hard hearing person/user of verbal language & $5.5 \%$ & $12.7 \%$ \\
\hline B2 & Deaf/user of sign language & $30.0 \%$ & $37.0 \%$ \\
\hline $\mathrm{C} 1$ & People with lower limb disabilities & $14.0 \%$ & $32.9 \%$ \\
\hline $\mathrm{C} 2$ & $\begin{array}{l}\text { People with disabilities of the } \\
\text { upper extremities, fine motor skills }\end{array}$ & $36.6 \%$ & $48.9 \%$ \\
\hline $\mathrm{D}$ & People with specific learning disabilities & $15.5 \%$ & \\
\hline E1 & People with chronic somatic diseases & $4.5 \%$ & $15.4 \%$ \\
\hline E2 & People with mental disorder & $27.8 \%$ & $32.2 \%$ \\
\hline
\end{tabular}


specific educational needs based on lower limb disabilities. This fact can be attributed to the respondents from individual non-medical fields of study, which are very physically demanding (e.g. physiotherapist, rescue ranger).

\section{Discussion}

Graphical outcomes from the previous section present answers to the questions from the survey. This survey has several limitations, of course. Its generalization can be problematic because of the low response rate among students. It is likely that the survey was answered only by students who were interested in this issue. And although it is seen that after graduation or during the study, respondents could change their opinion on this issue, certain conclusions can be formulated. Despite the above limitations, this study has particular relevance mainly for educational counseling in choosing a future profession.

In the case that classification of specific needs into categories $\mathrm{A}$ to $\mathrm{E}$ is kept, the survey can be concluded with the general recommendations: study of general medicine is fully manageable for students with special educational needs based on a lightweight visual or hearing impairment, specific learning disabilities and internal diseases and, in a limited form, for students with lower limb impairment. The study for the students with special educational needs based on severe visual or hearing impairment, locomotor impairment of the upper limbs, fine motoric skills and mental illness will be very complicated even after considerable adaptation from the faculty. And there is a high probability that such student will not be able to fulfil all obligations of the curriculum, and therefore the requirements for professional qualification. Of course, it always depends on the particular level of specific educational needs, because everyone is individual and everyone with is coping with "the same degree of" handicap in the different way.

Study of general medicine or rather the choice of non-medical (paramedical) profession?

It is often the case that a secondary school student with specific educational needs considers future applications in health and medicine because he has encountered more often with the environment of health care facilities. It may then, considering its specific educational needs, consider whether to choose (or, as will be shown below), a "simple" or "less demanding" study of some medical non-medical profession.

Comparison of the two surveys revealed the overwhelming consensus. During the percentage comparison of variants of answers some derogations has been found, which could be found in the category of specific educational needs of B2 (usage of sign language), where, in paramedical professions, respondents expected lower percentage of mastering study requirements, that will probably be given by greater need for direct communication with the patient. Significantly higher percentage of paramedical respondents also exclude full mastering of the study in categories of specific educational needs based on impairment of lower limbs. 
This fact may be given by proportion of respondents from individual non-medical fields of study, among which very physically demanding professions (e.g. physiotherapist, paramedic) were included.

In practice, there could be problems that may arise when teaching students with special educational needs, especially in patient care during clinical exercise, or in interactions with teachers, mentors of clinical practice and communication with a patient and a family (Ikematsu et al., 2014).

\section{Conclusion}

The issue regarding specific educational needs in healthcare and medicine is a very important topic in every case and it is very disputable. The applicants with special educational needs and their decisions about future professional specialization in health care should always be assessed realistically individually and with respect to future employability in the labor market. Although it is possible to modify the study, to maximally adapt it—of course, while observing all the given legal standards of vocational education-after graduation, the graduate goes into practice. He enters an ordinary medical facility, where he works in shifts is a common practice. Now the following questions arise: Will the employer be helpful and welcoming to the specific needs of a new employee? Will the employer allow the employee to adapt to the environment, for example, by modifying working environment or way of communication?

\section{References}

Chráska, M. (2007). Metody pedagogického výzkumu: Základy kvantitativního výzkumu/Methods of Pedagogical Research: The Basics of Quantitative Research. Praha: Grada.

Cook, V., Griffin, A., Hayden, S., Hinson, J., \& Raven, P. (2012). Supporting Students with Disability and Health Issues: Lowering the Social Barriers. Medical Education, 46, 564-574. https://doi.org/10.1111/j.1365-2923.2012.04267.x

Faigel, H. C. (1998). Changes in Services for Students with Learning Disabilities in U.S. and Canadian Medical Schools, 1991 to 1997. Academic Medicine, 73, 1290-1293. http://search.ebscohost.com/login.aspx?direct=true\&db=eric\&an=EJ579857\&scope=site https://doi.org/10.1097/00001888-199812000-00020

Ikematsu, Y., Mizutani, M., Tozaka, H., Mori, S., Egawa, K., Endo, M., \& Yokouchi, M. (2014). Nursing Students with Special Educational Needs in Japan. Nurse Education in Practice, 16, 674-679. https://doi.org/10.1016/j.nepr.2014.08.007

Kleňhová, M., \& Vojtěch, J. (2011). Úspěšnost absolventů středních škol ve vysokoškolském studiu, predčasné odchody ze vzdèlávání. http://www.nuov.cz/uploads/Vzdelavani_a_TP/VS_predcasne_odchody_2011_pro_ww w.pdf

Krhutová, L. (2013) Autonomie v kontextuzdravotníhopostižení/Autonomy in the Contects of Health Impairment. Boskovice: Ostravskáuniverzita v Ostravě v nakl. Albert.

McKendree, J., \& Snowling, M. J. (2011). Examination Results of Medical Students with Dyslexia. Medical Education, 45, 176-182.

https://doi.org/10.1111/j.1365-2923.2010.03802.x 
MEYS (2014). MŠMT Pravidla pro poskytování př́spěvku a dotací veřejným vysokým školám Ministerstvem školství, mládeže a tělovýchovy: Př́loha č. 3 Financování zvýšených nákladio na studium studentů se specifickými potřebami./Rules for Subsidy Supplying to Public Universities by the Ministry of Education, Youth and Sports: Annex No. 3 Financing of Increased Costs for the Study of Students with Special Needs. Praha: MŠMT. http://www.msmt.cz/file/33877_1_1/

Rosebraugh, C. J. (2000). Learning disabilities and Medical Schools. Medical Education, 34, 994-1000.

http://search.ebscohost.com/login.aspx?direct=true\&db=rzh\&an=106095943\&scope=si $\underline{\text { te }}$

Sochorová, H., \& Závacká, I. (2014). Specifickévzdělávacípotřeby a studiummedicíny/SEN and the Study of Medicine. In M. Kaleja (Ed.), Otázkyinkluzivníhovzdělávánístudentů se specifickýmipotrebami v pregraduálníprípravěl Issues of Inclusive Education of Students with SEN in Pre-Gradual Preparation (pp. 74-107). Ostrava: Ostravskáuniverzita.

Sochorová, H., \& Závacká, I. (2013). Specifické vzdělávací potřeby a realita studiave zdravotnických nelékařských oborech na vysoké škole/SEN and the Reality of the Study in Non-Medical Health-Care Study Programmes at a University. In M. Kaleja (Ed.), Budování rovného prístupu $v$ terciárním vzdělávání studentů se specifickými (vzdělávacími) potrebami/Building of an Equal Approach in Tertiary Education of Students with SEN(pp. 101-118). Ostrava: Ostravská univerzita.

Zezulková, E., \& Krhutová, L. (2009). Studenti se speciálními potřebami na vysoké škole: Studenti se senzorickým postižením/Students with SEN at a University: Students with Sensoric Impairment. Ostrava: Ostravská univerzita. 